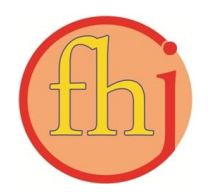

Faletehan Health Journal, 5 (1) (2018) 39-48

https://journal.Ippm-stikesfa.ac.id

ISSN 2088-673X| e-ISSN 2597-8667

\title{
Efikasi Diri dan Dukungan Sosial Pasien Hemodialisa Dalam Meningkatkan Kepatuhan Pembatasan Cairan
}

\author{
Ela Susilawati ${ }^{*}$, Kamaluddin Latief ${ }^{1}$, Khomarudin $^{1}$ \\ ${ }^{1}$ Sekolah Tinggi Ilmu Kesehatan Banten, Serpong, Tangerang Selatan, Indonesia \\ *Corresponding Author: e.susilawati@yahoo.com
}

\begin{abstract}
Abstrak
Peningkatan berat badan intradialitik akibat ketidakpatuhan asupan cairan pasien yang menjalani hemodialisa berdampak pada terjadinya penumpukan cairan secara kronis dan berisiko terhadap gangguan pada kardiovaskuler dan hipertensi, serta meningkatkan mortalitas dan morbiditas pada pasien dengan gagal ginjal kronik. Dukungan sosial menjadi salah satu faktor yang mendukung kepatuhan pasien dalam menjalankan terapi. Penelitian ini menggunakan rancangan mixed methods dengan desain sequential explanatory. Sampel kuantitatif dipilih menggunakan tehnik total sampling sebanyak 76 orang dan jumlah sampel kualitatif diambil secara purposive sampling sebanyak 6 orang. Pengumpulan data dilakukan dengan Chronic Kidney Disease Self-Efficacy Instrument dan Multidimentional Scale Perceived Social Support, serta wawancara. Analisis data kuantitatif dengan analisis deskriptif dan korelasi pearson. Analisis data kualitatif menggunakan teknik analisis model Miles dan Huberman. Hasil Uji korelasi Pearson, ada hubungan antara efikasi dan dukungan sosial dengan kepatuhan pembatasan cairan $(r=0.476 p=0.001)$ dan $(r=0.308$ $p=0.007$ ). Berdasarkan hasil wawancara mendalam didapatkan bahwa rasa haus menjadi penyebab ketidakpatuhan menjalankan program pembatasan asupan cairan. Diharapkan rumah sakit memberikan ruang khusus kepada keluarga pasien dan perawat memberi motivasi yang tinggi kepada pasien dalam menjalankan regimen terapinya.
\end{abstract}

Kata kunci: Efikasi diri, Dukungan sosial, Hemodialisa, Kepatuhan

\begin{abstract}
The increasing of intradialitic weight due to non-adherence to fluid intake of patients who undergoing hemodialysis is resulting in chronic buildup of fluid and risks for cardiovascular disorders and hypertension, as well as increased mortality and morbidity rate in patients with chronic renal failure. Social support is one of factors that support patient compliance in the therapy. This research design was mixed methods with sequential explanatory. Quantitative sample were selected by using total sampling technique of 76 patients, and the number of qualitative samples taken by using purposive sampling technique of 6 patients. Data were collected with Chronic Kidney Disease Self-Efficacy Instrument and Multidimentional Scale Perceived Social Support, as well as interviews. Quantitative data analized with pearson correlation, but qualitative data analized by using M iles and Huberman model analysis techniques. Pearson correlation showed that there was a relationship between efficacy and social support with fluid restriction compliance $(r=0.476 p$ $=0.001)$ and $(r=0.308 p=0.007)$. Based on the results of in-depth interviews found that the suffer from thirst cause patients to be non-compliance of fluid intake program restriction. It is expected that the hospital provides a special room to the patient's family, and the nurse gives high motivation to the patient while undergoing the therapy regimen.

Keywords: Self Efficacy, Social Support, Hemodialysis, Adherence
\end{abstract}




\section{Pendahuluan}

Penyakit Gagal Ginjal Kronik (GGK) atau chronic kidney disease adalah suatu proses penurunan fungsi ginjal yang progresif dan irreversibel sehingga tubuh gagal dalam mempertahankan proses metabolisme dan keseimbangan cairan elektrolit sehingga menyebabkan uremia (Smeltzer, 2008). Penyakit ginjal kronik merupakan penyakit yang terjadi saat kedua ginjal gagal dalam menjalankan fungsinya. Menurut Indonesian Renal Registry tahun 2011 melaporkan jumlah pasien hemodialis mencapai 4.977 dari 15.353 orang pada tahun 2007. Kenaikan jumlah pasien tersebut diikuti dengan penambahan jumlah unit-unit hemodialisa di rumah sakit se-Indonesia (IRR, 2011).

Penyakit ginjal kronis menurut hasil prevalensi di Indonesia pada tahun 2013 berdasarkan hasil diagnosis dokter terjadi peningkatan, dimana peningkatan tertinggi terjadi pada kelompok usia lebih dari 75 tahun sebesar $0,6 \%$ dan pada usia 55-74 tahun 0,5\%. Prevalensi pada laki-laki sebesar $0,3 \%$ lebih tinggi dibandingkan perempuan $(0,2 \%)$. Prevalensi lebih tinggi terjadi pada masyarakat perdesaan sebesar 0,3\% (Riskesdas, 2013).

Di Provinsi Banten penderita gagal ginjal berdasarkan diagnosis dokter yaitu sebesar 0,2 persen. Jadi dari 100 orang yang dilakukan pemeriksaan diagnosis oleh dokter ditemukan 20 orang yang menderita penyakit ginjal kronis. Angka tersebut masih tergolong tinggi bila dibandingkan dengan Provinsi DKI Jakarta yang hanya 0,1 persen (Riskesdas, 2013).

Hemodialisa adalah tindakan terapi yang paling banyak dipilih oleh pasien ginjal kronik. Proses terapi hemodialisa dilakukan minimal seminggu dua kali seumur hidup untuk membantu memperbaiki homeostasis tubuh penderita. Selama menjalani terapi hemodialisa, program terapeutik tentang kepatuhan terhadap pembatasan asupan cairan untuk meningkatkan qualitas hidupnya juga harus dijalani oleh pasien. Kepatuhan pasien tergambar dari seberapa jauh perilaku seseorang dalam melakukan pengobatan, mengikuti program diet, dan atau menjalankan perubahan pola hidup sesuai dengan yang disepakati atau rekomendasi dari petugas kesehatan (WHO, 2003).

Pengukuran kepatuhan pada pasien gagal ginjal kronik yang menjalani hemodialisa yaitu secara objektif dan subjektif (Clarke, 2014). Interdialytic weight gain merupakan pengukuran objektif dengan melihat rata-rata berat badan kering pasien gagal ginjal kronik untuk mengetahui tingkat kepatuhan pasien gagal ginjal kronik terhadap pembatasan cairan (Tsay, 2003 dalam Sulistyaningsih, 2011) dan pengukuran subjektif dilihat berdasarkan self report.

Berdasarkan hasil studi pendahuluan di rumah sakit di Jakarta yang dilakukan pada 9 orang pasien hemodialisa didapatkan data sekitar $33 \%$ pasien terjadi peningkatan Interdialytic weight gain rata-rata dan $33 \%$ pada katagori bahaya. Rasa haus menjadi faktor penyebab tidak patuhnya pasien ginjal kronik yang menjalani hemodialisa (Sulistyaningsih, 2011). Dalam studi lain, penelitian dengan desain Retrospective observasional dari 4.633 responden yang terdaftar dalam The Swedia Dialysis Database and Swedia Registry of Active treatment of Uremia tahun 2002 - 2006, melaporkan sekitar 30\% pasien tidak patuh terhadap pembatasan asupan cairan. Ketidakpatuhan tersebut ditandai dengan banyaknya pasien yang mengalami kenaikan berat badan interdialitik lebih dari 3,5\% (Lindberg, 2008).

Faktor-faktor yang mempengaruhi kepatuhan asupan cairan pada pasien gagal ginjal kronik dengan hemodialisa di RSUD Prof. Dr. Magrono Soekardjo, menyebutkan berdasarkan hasil uji statistik bahwa ada hubungan antara pendidikan pasien, keterlibatan perawat, keterlibatan keluarga, konsep diri, dan tingkat pengetahuan pasien terhadap tingkat kepatuhan asupan cairan pasien gagal ginjal kronik (Kamaluddin, 2009). Masih tingginya angka ketidakpatuhan pasien ginjal kronik yang menjalani hemodialisa terhadap pembatasan asupan cairan memaksa perawat harus memperhatikan terkait faktor psikologis dan sosial yang mempengaruhi kepatuhan pasien ginjal kronik salah satunya adalah efikasi diri. Efikasi diri merupakan keyakinan akan kemampuan individu untuk dapat mengorganisasi dan melaksanakan serangkaian tindakan yang dianggap perlu untuk mencapai suatu hasil yang diinginkan (Bandura, 1994).

Selain efikasi diri, dukungan sosial juga merupakan salah satu faktor yang dapat mempengaruhi kepatuhan intake cairan pada pasien gagal ginjal kronik. Menurut Sarafino (2006) dalam (Azahra, 2012) yang dimaksud 
Faletehan Health Journal, 5 (1) (2018) 39-48 https://journal.Ippm-stikesfa.ac.id ISSN 2088-673X| 2597-8667

dukungan sosial adalah bantuan yang diterima individu dari orang lain atau kelompok disekitarnya yang membuat penerima merasa nyaman, diperhatikan, dicintai dan dihargai, yang dapat diperoleh dari teman, saudara, dan orang tua serta orang-orang disekitar.

Hubungan antara dukungan sosial dengan kepatuhan pembatasan cairan pasien gagal ginjal kronik, yaitu semakin positif dukungan yang diberikan akan meningkatkan kepatuhan pembatasan cairan (Andriani, 2013). Pasien gagal ginjal akan lebih termotivasi untuk mengikuti anjuran teraupetik jika mendapat dukungan sosial yang positif dari orang sekitar (Cohen, 2007). Pada penelitian ini kepatuhan hanya dilihat secara kuantitatif saja sehingga tidak tampak secara mendalam alasan yang menyebabkan ketidakpatuhan pada pasien.

Berdasarkan uraian di atas dapat dilihat pula bahwa efikasi diri dan dukungan sosial merupakan faktor-faktor penting yang dapat berperan terhadap kepatuhan intake cairan secara mendalam pada penderita gagal ginjal yang menjalani terapi hemodialisis. Oleh karena itu peneliti tertarik untuk meneliti keterkaitan antara efikasi diri dan dukungan sosial terhadap kepatuhan pembatasan intake cairan pada pasien gagal ginjal kronik yang menjalani hemodialisa di RSU Kabupaten Tangerang.

\section{Metode Penelitian}

Penelitian ini dilaksanakan selama dua minggu terhitung tanggal 27 Juli 2016 sampai dengan 6 Agustus 2016 di RSU Kabupaten Tangerang. Pada proses penelitian, peneliti sebelumnya memberikan penjelasan kepada pasien tentang maksud dan tujuan penelitian (informed consent). Selanjutnya pasien yang bersedia menjadi responden penelitian mengisi form dan menandatangani lembar persetujuan menjadi responden penelitian. Pada penelitian ini, peneliti melakukan pengambilan dengan kuesioner kepada sampel sejumlah 76 orang yang memenuhi kriteria. Kemudian peneliti melengkapi data hasil jawaban dari pertanyaan terbuka dari kuesioner kepada 6 orang pasien hemodialisa dengan wawancara langsung.

Metode penelitian menggunakan penelitian mixed methods dengan rancangan Sequential explanatori. Populasi penelitian ini seluruh pasien gagal ginjal dengan hemodialisa di Unit
Hemodialisa RSU Kabupaten Tangerang. Metode sampling pada penelitian kuantitatif menggunakan metode total sampling sebanyak 76 responden, dengan kriteria inklusi pasien yang berusia $>18$ tahun, penderita penyakit gagal ginjal yang merupakan pasien rawat jalan yang rutin menjalani terapi hemodialisa 2 kali seminggu di unit hemodialisa Rumah Sakit Umum Tangerang, sadar dan mampu berkomunikasi dengan baik, bisa baca dan tulis, bertempat tinggal bersama keluarga atau kerabat karena berkaitan dengan tujuan untuk mengetahui dukungan sosial yang diterima oleh subjek penelitian, dan bersedia menjadi subjek penelitian.

Pemilihan sampel pada desain kualitatif menggunakan purposive sampling sebanyak 6 responden dengan kriteria usia pasien 50-60 tahun, tingkat pendidikan pasien berdasarkan tingkatan pendidikan dasar (SD, SMP), pendidikan menengah (SMA), dan pendidikan tinggi (D3, S1), karakteristik demografi pasien (desa dan kota), kriteria yang digunakan dalam membedakan pasien kota/ desa yaitu berdasarkan pekerjaan pasien. Salah satu ciri-ciri kota adalah mata pencarian non-agraris, sehingga peneliti mengklasifikasikan berdasarkan pekerjaan yang tertera pada kartu tanda penduduk sebagai petani dan nelayan merupakan masyarakat desa, jaminan kesehatan (BPJS) dan umum/ non BPJS; kriteria yang digunakan dalam membedakan jaminan kesehatan pasien dapat dilihat pada rekam medik/ status kesehatan pasien, lama menjalani hemodialisa; diklasifikasikan kurang dari 6 bulan dan lebih dari 6 bulan dan perbedaan selisih berat badan antara awal pemeriksaan dan pemeriksaan kedua ketika melakukan hemodialisa.

Instrumen pengukuran kepatuhan mengunakan IDWG (Intradialitic Weight Gain), sedangkan efikasi diri menggunakan Chronic Kidney Disease Self Efficacy yang dikembangkan oleh Chiu Chu Lin, 2011 dan Multidimentional Perceived Social Support yang dikembangkan oleh Gregory D. Zimet, 1998 untuk mengukur dukungan sosial. Pengumpulan data kualitatif menggunkan teknik wawancara mendalam.

Analisis data kuantitatif menggunakan uji parametrik yaitu uji pearson corelation test, sedangkan pada data kualitatif menggunakan analisis Miles and Miles \& Huberman yaitu dengan menentukan tema-tema. 


\section{Hasil Penelitian}

Berdasarkan hasil penelitian yang telah dilakukan terhadap 76 pasien hemodialisa di Unit Hemodialisa RSU Kabupaten Tangerang bulan Juli sampai dengan Agustus 2016, diperoleh data seperti yang tertuang pada tabel 1 .

Pada tabel 1 menunjukkan karakteristik pasien gagal ginjal di Unit Hemodialisa RSU Kabupaten Tangerang yaitu pasien dengan jenis kelamin laki-laki ada 41 (53.9\%), pendidikan pasien hemodialisis mayoritas yaitu berpendidikan SMA berjumlah 30 (39.5\%).

Pada tabel 2 menunjukan rata-rata umur adalah 51.38 tahun (CI 95\%; 48.58 - 54.25), dengan SD 12.47 tahun. dengan rata-rata lama menjalani hemodialisis pasien gagal ginjal kronik di unit Hemodialisa RSU Kabupaten Tangerang yaitu 3.18 tahun (CI 95\%; 2.56-3.86).

Pada tabel 3 terlihat bahwa rata-rata kenaikan IDWG adalah $2.85 \mathrm{~kg}$ (CI 95\%; 2.64 - 3.05), dengan SD $0.94 \mathrm{~kg}$. Kenaikan IDWG terendah $0.75 \mathrm{~kg}$ dan tertinggi $5.00 \mathrm{~kg}$.

Sebagian informan mengatakan kenaikan berat badannya meningkat karena sulit mamatuhi program-program terapi yang direkomendasikan ahli gizi dan petugas kesehatan seperti pembatasan asupan cairan diakibatkan karena rasa haus. “..........kadang-kadang melanggar, ya namanya haus gimana ya......karna haus ya kadang-kadang saya minum.........." (I.2) “........minum kali ya, banyak minum.......awalnya haus terus.......kayak ga bisa mikir takut kebanyakan kadang minumminum aja....."(I.6)

“......panas awalnya panas makanya minum banyak,......iya haus......”(I.4)

Tabel 1. Distribusi frekuensi karakteristik pasien hemodialisis $(n=76)$

\begin{tabular}{lcc}
\hline $\begin{array}{c}\text { Karakteristik / } \\
\text { Kategori }\end{array}$ & Jumlah & Persentase \\
\hline $\begin{array}{c}\text { Jenis Kelamin } \\
\text { Laki-Laki }\end{array}$ & 41 & 53.9 \\
Perempuan & 35 & 46.1 \\
\hline $\begin{array}{c}\text { Pendidikan } \\
\text { SD }\end{array}$ & 16 & 21.1 \\
SMP & 13 & 17.1 \\
SMA & 30 & 39.5 \\
PT & 17 & 22.4 \\
\hline \multicolumn{1}{c}{ Total } & 76 & 100 \\
\hline
\end{tabular}

Tabel 2. Karakteristik responden berdasarkan umur pasien dan lama menjalani hemodialisis $(\mathrm{n}=76)$

\begin{tabular}{lcccc}
\hline \multicolumn{1}{c}{ Karakteristik } & Mean & SD & Min-Maks & 95\% CI \\
\hline Umur Pasien (tahun) & 51.38 & 12.47 & $19-77$ & $48.58-54.25$ \\
\hline Lama Menjalani hemodialisa (tahun) & 3.18 & 2.87 & $0.17-13$ & $2.56-3.86$ \\
\hline
\end{tabular}

Tabel 3. Rata-rata, standar deviasi, minimum dan maksimum kepatuhan pembatasan intake cairan pasien hemodialisis berdasarkan kenaikan IDWG, efikasi diri dan dukungan sosial $(\mathrm{n}=76)$

\begin{tabular}{lcccc}
\hline \multicolumn{1}{c}{ Variabel } & Mean & SD & Min-Maks & 95\% CI \\
\hline Kenaikan BB Interdialisis $(\mathrm{Kg})$ & 2.85 & 0.94 & $0.75-5.00$ & $2.64-3.05$ \\
\hline Efikasi diri Pasien & 7.86 & 1.21 & $3.00-9.84$ & $7.56-8.12$ \\
\hline Dukungan Sosial & 1.50 & 0.12 & $1.15-1.71$ & $1.48-1.53$ \\
\hline
\end{tabular}


Faletehan Health Journal, 5 (1) (2018) 39-48 https://journal.Ippm-stikesfa.ac.id ISSN 2088-673X | 2597-8667

Tabel 3 menunjukan rata-rata skor efikasi diri pasien adalah $7.86(95 \% ; 7.56$ - 8.12), dengan hasil skor efikasi diri pasien sebagian besar yaitu 7.86 yang artinya pada kategori baik. Sedangkan pada hasil wawancara didapatkan bahwa sebagian besar informan memiliki efikasi diri yang baik karena mereka bisa membatasi jumlah asupan cairan yang telah direkomendasikan yaitu sekitar $600 \mathrm{ml} /$ hari. Selain itu, mereka dapat menerapkan memanajemen rasa haus dengan menggerus es batu, serta ada juga yang menggunakan gelas kecil saat ingin minum, atau minumya hanya sedikit-sedikit.

“.........pertama minum dulu kita batasin, interuksi kan satu kali 24 jam itu kan $600 \mathrm{ml}$ itu saya jaga, kisaran satu botol aqua lah itu saya jaga.......minum tetep saya jaga........sehari semalam iya itu ga lebih dari $600 \mathrm{ml}$...." (I.1)

“....yaaa paling sekitar 600....600 ml...” (I.4)

“.........iya itu ibu ngunyah batu es aja gtu, ga minum sekali satu gelas gitu nggak......udah tau soalnya kalau jadi batu es jadinya dikit... biarpun setengah air kan jadinya ga bakal setengah kalau jadi es batu........” (I.5) "........iya itu peraturanya minum kan ga boleh banyak-banyak......iya dilakuin itu minumya dikit-dikit aja... paling tiga gelas, kalau haus empat gelas, tapi gelasnya gelas kecil......"(I.3)

Sebagian besar informan mengatakan mampu untuk membatasi diri terhadap keinginan untuk mengkonsumsi makanan dan buah-buahan yang tidak diperbolehkan oleh petugas kesehatan.

“......kalau makanan itu kalau misalkan ga boleh nggak, misalnya kayak pisang, belimbing, santan, semangka kan ga boleh, pokoknya buah-buahan yang ngandung air....itu nggak nggak saya makan...." (I.5)

“......cuman penyedap aja nggak mecin yang nggak.....asin sih masih cuman dikurangi aja jumlahnya.....” (I.1)

“......yang ga boleh kan banyak makan buahbuahan seperti pisang.....pisang sama jeruk ya.....yang dimakan pepaya aja....nggak pernah makan yang asin-asin....santansantan juga jarang......” (I.3) “.....pola makan sih biasa sih normal aja kalau menurut saya, makanya gak ada artinya gak ada macem-macem lah....." (I.2)

“.....santan-santan ga makan...buah-buahan nggak selain pepaya...kata dokter yang boleh pepaya aja ya bapak nurut....” (I.4)

“.....nggak asin mah ga pernah....buahan yang ga boleh pisang....yang boleh pepaya.....nggak makan asin-asin takut darah tinggi" (I.6)

Pada tabel 3 menunjukan rata-rata skor dukungan sosial yang diterima pasien adalah 1.50 $(95 \% ; 1.48-1.53)$. Berdasarkan hasil analisis diperoleh bahwa skor dukungan sosial mayoritas pasien 1,50 yang artinya dukungan sosial yang diterima pasien baik. Adapun, hasil wawancara semua informan mengatakan selalu memberi dukungan kepada anggota keluarganya yang sakit baik berupa motivasi, perhatian, dan semangat hidup.

“......iyhh motivasi hidup, jadi jangan ngeluhlah karena ini cobaan......jadi kita harus optimis namanya umur mah kita ga tahu cuman kalau sehat mah tetep harus......” (I.1)

“.....ohhh bagus terutama istri, anak-anak ya kan......ya yang sabar ya.......kasih support....." (I.2)

“.......iyhh diantar nanti juga dijemput....iyh dukung aja, jalanin aja, kayak ya nikmatin aja yang penting lancar...." (I.3)

“......iyh ngedukung sетиа.... sетиа ngedukung harus cuci darah.....pernah kesini kalau lagi prei kuliah......semangat anak bapak nunggu bapak kalau lagi hemodialisa" (I.4)

“......ya ini sih mendukung aja udah diterima aja.....diterima aja itu udah kehendak Allah SWT......kalau dulu diantar......kadang pulang dijemput....ya ngedukung aja sih ya udah ma yang sabar aja...." (I.5)

“......ya dianter gitu ikhlas aja......iyh malahan dia suka ngingetin jangan dimakan yang dilarang.....semangat aja mereka mahh...kadang dianter suami ....anakanak...." (I.6)

Hasil wawancara Informan menyebutkan bahwa teman-teman selalu memberikan dukungan 
selama sakit baik berupa motivasi, dan semangat hidup.

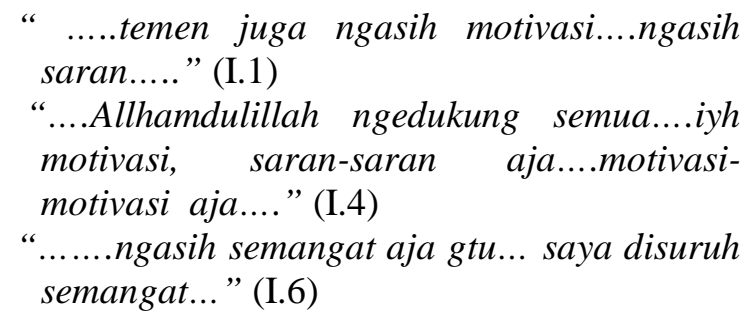

Berdasarkan wawancara peneliti terhadap responden poin penting terkait dukungan yang diberikan oleh perawat hemodialisa sangat positif, misalnya dengan memberikan motivasi, perhatian, dan sopan.

“......bagus baik-baik.....ngasih saransaran cara merawat..... harus optimis ....pola makan teratur, istirahat banyak....." (I.1)

“......ohh perawat sini bagus....dari pada perawat RS X kasar-kasar.....harus sabar ingat jangan minum banyak-banyak....baikbaik disini baik-baik....” (I.2)

"......baik sih ramah-ramah ya.....ngak cuek....jadi kalau kita perlu sesuatu langsung ditanggapi...." (I.3)

"......Allhamdulillah semua baik-baik....." (I.6)

Hubungan efikasi diri dengan kepatuhan pembatasan cairan pasien hemodialisis menunjukan hubungan sedang $(r=0.476)$ dan berpola positif artinya semakin baik efikasi diri pasien maka akan semakin tinggi kepatuhan pasien dalam membatasi asupan cairan. Nilai koefisien dengan determinasi 0.225 artinya persamaan garis regresi yang diperoleh dapat menerangkan 22.5\% variasi kepatuhan pembatasan cairan pasien hemodialisis atau persamaan garis yang diperoleh cukup baik untuk menjelaskan variabel kepatuhan pembatasan cairan pasien. Hasil uji statistik didapatkan ada hubungan yang signifikan antara efikasi diri dengan kepatuhan pembatasan intake cairan pasien hemodialisis ( $p$ value $=0.000$ ) .

Hubungan dukungan sosial dengan kepatuhan pembatasan cairan pasien hemodialisis menunjukan hubungan sedang $(r=0.328)$ dan berpola positif artinya semakin positif dukungan yang diterima pasien maka akan semakin tinggi kepatuhan pasien dalam membatasi asupan cairan. Nilai koefisien dengan determinasi 0.107 artinya persamaan garis regresi yang diperoleh dapat menerangkan $10.7 \%$ variasi kepatuhan pembatasan cairan pasien hemodialisis atau persamaan garis yang diperoleh cukup baik untuk menjelaskan variable kepatuhan pembatasan cairan pasien. Hasil uji statistik didapatkan ada hubungan yang signifikan antara dukungan sosial dengan kepatuhan pembatasan intake cairan pasien hemodialisis $(p$ value $=0.007)$.

\section{Pembahasan}

Berdasarkan hasil tersebut didapatkan sebagian besar kepatuhan pasien pada kategori baik yang ditandai dengan kenaikan berat badan waktu interdialisis pasien yaitu 2,85 . Peneliti berasumsi bahwa faktor yang pendidikan tinggi menjadi salah satu penyebab kepatuhan terhadap pembatasan cairan. Selain itu faktor lamanya menjalani hemodialisa pasien yang rata-rata tergolong lama juga dapat menjadi faktor penyebab kepatuhan pasien gagal ginjal kronik, dimana semakin lama pasien menjalani hemodialisa maka akan semakin patuh.

Tabel 4. Analisis korelasi dan regresi efikasi diri dan dukungan sosial dengan kepatuhan pembatasan intake cairan pasien hemodialisa $(n=76)$

\begin{tabular}{|c|c|c|c|c|}
\hline Variabel & $\mathrm{R}$ & $\mathrm{R}^{2}$ & Persamaan Garis & $P \quad$ Value \\
\hline Efikasi Diri dan Kepatuhan & 0.476 & 0.225 & $\mathrm{IDWG}=5.75+(-0.36)$ Efikasi diri & 0.000 \\
\hline Dukungan Sosial dan Kepatuhan & 0.328 & 0.107 & IDWG $=6.52+(-2.43)$ dukungan & 0.007 \\
\hline
\end{tabular}


Faletehan Health Journal, 5 (1) (2018) 39-48

https://journal.Ippm-stikesfa.ac.id ISSN 2088-673X| 2597-8667

Pasien yang berjenis kelamin laki-laki dalam penelitian ini lebih banyak yang patuh dari pada perempuan. Hal ini dijelaskan oleh penelitian sebelumnya bahwa laki-laki cenderung memiliki adaptasi terhadap panas yang baik dibandingkan dengan wanita, selain itu kebutuhan cairan lakilaki yang lebih rendah dibandingkan perempuan serta hal tersebut yang menjadi alasan jika pria akan lebih patuh dibandingkan wanita (Arnold, 2008).

Dari hasil wawancara penyebab beberapa pasien tidak patuh yaitu sebagian besar karena rasa haus. Hasil tersebut sesuai dengan hasil studi pendahuluan di salah satu rumah sakit di Jakarta yang melakukan terhadap 9 orang yang menjalani hemodialisa didapatkan $33 \%$ pasien mengalami peningakatan berat badan diantara waktu dialisis pada kategori rata-rata dan $33 \%$ pasien pada kategori bahaya. Hal tersebut terjadi akibat pasien belum mematuhi pembatasan cairan yang diprogramkan, mereka sering melanggar jumlah intake cairan yang sebenarnya dibatasi terutama karena rasa haus (Sulistyaningsih, 2011).

Rasa haus dapat diakibatkan karena adanya penurunan volume cairan ekstra seluler melalui sistem renin, angiotensin, dan aldosteron. Sekresi renin meningkat karena hipovolemi yang menyebabkan kenaikan angiotensin II yang beredar. Angiotensin II bekerja pada organ subforniks, yaitu daerah reseptor khusus dalam diensefalon yang merangsang daerah neural yang berhubungan dengan haus (Guyton \& Hall, 2014).

Pada pasien gagal ginjal (GGK) dalam pembuluh darah beredar zat-zat sisa metabolisme tubuh, dimana yang seharusnya dibuang melalui urin. Tetapi pasien GGK gagal membuang zat sisa metabolism tersebut, sehingga hal tersebut tentunya akan mempengaruhi viskositas plasma yang dapat berakibat terjadinya peningkatan respon angiotensin II untuk memberi sinyal pada otak agar supaya meningkatkan asupan cairan melalui mekanisme rasa haus.

Berdasarkan hasil skor efikasi diri responden sebagian besar pada kategori baik. Hal ini karena salah satu faktor yaitu motivasi diri pasien yang tinggi terhadap kesembuhan penyakit yang diderita meskipun ada sebagian pasien yang sudah meyakini dan memahami jika penyakitnya tidak akan bisa sembuh, tetapi pasien juga beranggapan paling tidak penyakitnya tidak terjadi komplikasi lanjut.
Hasil tersebut sesuai dengan hasil penelitian Nadi (2014) yang menunjukkan ada hubungan antara dukungan sosial dan motivasi dengan kepatuhan pembatasan asupan cairan pada pasien penyakit ginjal kronik yang menjalani hemodialisa. Penelitian tersebut menunjukkan tingkat signifikansi $\mathrm{p}=0,000$ yang artinya terdapat hubungan antara kedua variabel. Hal ini dapat diartikan bahwa semakin tinggi dukungan sosial dan motivasi, semakin patuh pasien terhadap pembatasan asupan cairan.

Pasien dengan tingkat keyakinan yang baik, akan berniat untuk membatasi intake cairan, sesuai dengan yang disarankan oleh petugas kesehatan. Salah satunya pembatasan intake cairan yang diperbolehkan adalah antara 500-600 $\mathrm{ml}$ untuk 24 jam. Pembatasan intake cairan pada pasien gagal ginjal kronik bertujuan untuk menghindari adanya retensi cairan berlebih dalam tubuh yang dapat berakibat pada peningkatan resiko terjadinya edema, gagal jantung kongestif, hipertensi, dan efusi pleura, sehingga menyebabkan pasien menjadi sesak napas (Guyton \& Hall, 2014).

Selain itu, pasien harus mampu dan bisa membatasi jumlah asupan kalium dan natrium karena mineral ini dapat menumpuk dalam tubuh sehingga menyebabkan hiperkalemia dan hipernatremia. Kadar kalium yang tinggi dalam tubuh akan mengakibatkan irama jantung yang tidak normal, bahkan dapat mengakibatkan kematian. Tanda yang biasa muncul saat seseorang mengalami hiperkalemia biasanya adalah kelemahan otot, diare, dan kram abnormal. Kadar natrium dalam tubuh melebihi batas normal yaitu 1 hingga 2,3 gram perhari akan berakibat terjadinya peningkatan jumlah cairan dalam tubuh, dimana sifat dari natrium adalah dapat mengikat air sehingga hal tersebut akan berakibat pada peningkatan tekanan darah (Smeltzer, 2008).

Berdasarkan hasil penelitian ini, diperoleh bahwa skor dukungan sosial mayoritas pasien adalah 1,50 yang artinya dukungan sosial yang diterima pasien adalah baik. Hal tersebut tentunya tidak terlepas dari peran serta keluarga pasien dalam perawatan yang selalu memberikan bantuan dan dukunganya. Dukungan sosial dapat berpengaruh terhadap perubahan perilaku kesehatan, mekanisme fisiologis, dan psikologis. Bentuk dukungan sosial yang dapat diberikan seperti bantuan emosional, usaha nyata, berbagi 
informasi atau memberikan nasihat (Thong, 2007). Dukungan ini akan membuat individu yang menerimanya merasa diperhatikan dan diterima, sehingga membawa kekuatan baru yang berguna untuk terus memotivasi pasien yang berdampak pada kepatuhan program intake cairan.

Berdasarkan hasil analisis, efikasi diri memiliki hubungan positif terhadap kepatuhan membatasi intake cairan pada pasien gagal ginjal. Hal tersebut sesuai dengan kondisi dilapangan yang menyebutkan bahwa pasien yang disiplin terhadap intake cairan memiliki keyakinan yang kuat untuk bisa sembuh, walaupun mereka juga mengerti bahwa penyakitnya saat ini tidak akan bisa sembuh.

Selain itu juga berdasarkan hasil penelitian diketahui bahwa lama menjalani hemodialisa pasien rata-rata 3,19 tahun. Hal tersebut yang membuat pasien sudah menerima kondisi penyakit saat ini. Sesuai dengan penelitian yang dilakukan Novitasari yang menjelaskan ada 63,3\% responden yang tergolong lama menjalani hemodialysis (>24 bulan) tergolong pada fase acceptance atau penerimaan. Semakin lama pasien hemodialisis beradaptasi, maka semakin baik mekanisme koping karena pasien telah mendapatkan pendidikan (Novitasari, 2015).

Selain itu tingkat pendidikan sering dihubungkan dengan pengetahuan. Seseorang yang berpendidikan tinggi diasumsikan lebih mudah menyerap informasi, sehingga pemberian asuhan keperawatan dapat disesuaikan dengan tingkat pendidikan yang mencerminkan tingkat kemampuan pemahaman dan kemampuan menyerap edukasi self-care (Istanti, 2011). Hasil penelitian ini juga sesuai dengan penelitian sebelumnya yang menyatakan bahwa efikasi diri memberikan kontribusi signifikan pada kepatuhan pasien dalam menjalani pengobatan, selain itu efikasi diri memiliki hubungan positif dengan kepatuhan. Hal ini berarti efikasi diri dapat digunakan sebagai prediktor kepatuhan pasien dalam menjalani pengobatan (Pertiwi, 2015).

Penelitian Mahmoud (2015) dengan sampel berjumlah 120 pasien juga menunjukan adanya hubungan positif antara health locus of control dan efikasi diri $(r=0,315 ; p=0,000)$, dan adanya hubungan positif antara efikasi diri dan kemampuan perawatan diri pasien gagal ginjal kronik $(\mathrm{r}=0,146 ; \mathrm{P}=0.000)$. Hasil penelitian ini juga sesuai dengan penelitian yang dilakukan Jhon (2012) pada 100 orang pasien hemodialisa menunjukan hasil analisis ada hubungan positif antara efikasi diri dan pembatasan intake cairan $(\mathrm{r}=0.56) \mathrm{p}<0.001)$.

Berdasarkan hasil penelitian diatas juga menyebutkan bahwa ada hubungan signifikan positif antara dukungan sosial dengan kepatuhan pembatasan intake cairan pasien hemodialisis. Peneliti berasumsi bahwa adanya dukungan sosial yang baik sehingga akan memberikan perhatian yang lebih pada pasien selama sakit. Kemudian hal tersebut membuat sebagian besar pasien dapat mematuhi terapi pembatasan cairan. Hal tersebut sesuai dengan penjelasan Hartanti (2002) dalam Azahra (2012) yang mengatakan bahwa dukungan sosial dapat mencegah perasaan tertekan, yaitu mencegah apa yang dipandang individu sebagai stressor yang diterimanya.

Selain itu juga pasien yang mendapat dukungan sosial yang positif dari orang sekitar dapat menghindarkan pasien dari stress dan depresi. Stress dan depresi dapat membuat pasien sulit mematuhi semua program terapi yang diberikan. Stres yang tinggi dan berlangsung dalam jangka waktu yang panjang atau lama dapat memperburuk kondisi kesehatan. Tetapi dengan adanya dukungan sosial yang diterima oleh individu yang sedang mengalami atau menghadapi stres bahkan depresi akan dapat mempertahankan daya tahan tubuh dan meningkatkan kesehatan individu tersebut (Azahra, 2012).

Hasil penelitian ini juga sejalan dengan penelitian yang dilakukan oleh Ahrari (2014) pada 237 responden hemodialisa di Iran yang menjelaskan ada hubungan negatif antara dukungan sosial terhadap ketidakpatuhan diet ( $\mathrm{r}=$ $-0,654, \quad \mathrm{p}=<0,001)$ dan ketidakpatuhan pembatasan cairan $(\mathrm{r}=-0,672, \mathrm{p}=<0.001)$ pada pasien gagal ginjal kronik. Artinya semakin rendah dukungan sosial maka tingkat ketidakpauhan terhadap diet dan pembatasan cairan pasien akan semakin tinggi. Penelitian lain yang menunjang pada 51 responden yang diambil menjelaskan berdasarkan uji analisis bahwa ada hubungan antara dukungan sosial $(\mathrm{p}=0,046)$ dengan kepatuhan pembatasan cairan pasien gagal ginjal kronik yang menjalani hemodialisa di RSUD Kota Semarang (Andriani, 2013).

\section{Simpulan}

Dukungan sosial pada pasien hemodialisa dapat berasal dari orang sekitar seperti keluarga 
Faletehan Health Journal, 5 (1) (2018) 39-48 https://journal.Ippm-stikesfa.ac.id ISSN 2088-673X | 2597-8667

dan teman. Efikasi yang kuat membuat penderita gagal ginjal yang hemodialisa patuh terhadap serangkain pengobatan dan terapi yang dijalankan. Diharapakan perawat dapat terus memberikan motivasi dalam meningkatkan efikasi diri pasien dalam membatasi asupan intake cairan.

\section{Referensi}

Ahrari, S., Moshki, M., \& Bahrami, M. (2014). The Relationship Between Social Support and Adherence of Dietary and Fluid Restrictions Among Hemodialysis Patients In Iran. . Journal of Caring Science. , 3(1): 1119.

Andriani, Deni Arif. (2013). Hubungan Dukungan Sosial Terhadap Kepatuhan Pembatasan Cairan Pasien Ginjal Kronik Yang Menjalani Hemodialisa Di RSUD Kota Semarang : diunduh tanggal 12 Maret 2016. Nursing journal.

Arnold, T. L. (2008). Predicting Fluid Adherence in Hemodialysis Patients Via The Illness Perception Questionere-Revided. Dissertation Georgia State University .

Azahra, M. (2012). Peran Konsep Diri dan Dukungan Sosial Terhadap Tingkat Depresi Pada Pasien Yang Menjalani Hemodialisa. Diakses pada 28 Januari 2016.

Bandura, A. (1994). Self - efficacy. In V. S. Ramachaudran (Ed.), Encyclopedia of human behavior (Vol. 4, pp. 71 - 81). New York: Academic Press. (Reprinted in $H$. Friedman [Ed.], Encyclopedia of mental health. . San Diego; New York: Academic Press 1998.

Bandura, Albert. (1994). Teori efikasi. diri diperoleh melalui http://www.des.emory.edu/mfp/BanEncy.html pada tanggal 12 November 2015.

Clarke, S. F. (2014). Nonadherence in Dialysis Patients: Prevalence, Measurement, Outcome, and Psychological Determinants. In Seminars in dialysis Vol. 27, No. 1 , pp. 42-49.

Cohen, S. D. (2007). Social Support and Chronic Kidney Disease: An Update. . Advance in Chronic Kidney Disease. Vol. 14 No. 4 (Okt) 2007 , pp 335-344.

Guyton, A. C., \& Hall., J. E. (2014). Fisiologi Kedokteran Edisi 12 . Singapore: Elsevier.
Hastono, S. P. (2007). Analisis Data Kesehatan. Depok: FKM UI.

IRR, I. R. (2011). 4th Report of Indonesian Renal Registry 2011. Jakarta: Persatuan Nefrologi Indonesia (PERNEFRI).

Istanti, Y. P. (2011). Faktor-Faktor Yang Berkontribusi Terhadap Interdialytic Weight Gain Pasien Ginjal Kronik Yang Menjalani Hemodialisa. Mutiara Medika. Mei 2011. Vol. 11 No.2: , 118-130.

John, A. P. (2012). The Relationship between Self-efficacy and Fluid, and Dietary Compliance in Hemodialysis Patients Diunduh 11 Maret 2016. Nefrology Journal University of Nevada, Las Vegas .

Lindberg. (2008). Non-adherence to Fluid Restrictions: Prevalence and The of SelfEfficacy Among Haemodialysis Patients. Doctoral Thesis Department of Public Health and Caring Sciences, Uppsala University. Diunduh tanggal 10 Maret 2016.

Mahmoud, S. N. (2015). Association between Health Locus of Control, Self-care and Selfefficacy in Patients with End Stage Renal Disease Undergoing Hemodialysis. Life Science Journal , 2(11).

Miles, M. B., \& Huberman., M. (2009). Analisis Data Kualitatif. hal 389-456. Jakarta: UI Press.

Nadi, H. I. (2014). Hubungan Dukungan Sosial dan Motivasi Dengan Kepatuhan Pembatasan Cairan Pasien Ginjal Kronik Yang Menjalani Hemodialisa Di RSUD Dr.M.M. Dunda Limboto Kabupaten Gorontalo. Diunduh tanggal 12 Maret 2016.

Novitasari, D. (2015). Hubungan Lama Menjalani Hemodialisa Terhadap Tingkat Kepatuhan Pembatasan Asupan Cairan Pada Pasien Gagal Ginjal Kronik Menjalani Hemodialisa Di RS PKU Muhammadiyah Unit 1 Yugyakarta.

Nurchayati, S. (2010). Analisis Faktor-faktor Yang Berhubungan Dengan Kualitas Hidup Pasien Penyakit Ginjal Kronik Yang Menjalani Hemodialisa Di RSI Fatimah Cilacap dan RSUD Banyumas. diunduh tangga. Thesis from Faculty of Nursing Indonesian University .

Pertiwi, I. (2015). Hubungan Dukungan Pasangan dan Efikasi Diri Dengan Kepatuhan Menjalani Pengobatan Pada penderita DM 
Faletehan Health Journal, 5 (1) (2018) 39-48 https://journal.Ippm-stikesfa.ac.id ISSN 2088-673X | e-ISSN 2597-8667

Tipe II di RSUD Dr. Moewardi Surakarta. Diakses 10 Maret 2016.

Riskesdas. (2013). Riset Kesehatan Dasar Litbangkes Kementerian Kesehatan RI Jakarta Tahun 2013. Jakarta: Kemenkes RI.

Riyanto, W. (2011). Hubungan Antara Penambahan Berat Badan Di Antara Dua Waktu Hemodialisis Terhadap Kualitas Hidup Pasien Penyakit Ginjal Kronik Yang Menjalani Hemodialisa Di Unit Hemodialisa IP2K RSUP Fatmawati Jakarta. Thesis from Faculty of Nursing Indonesia .

Smeltzer, S. C. (2008). Keperawatan Medikal Bedah Edisi 8 Vol.2. . Jakarta: EGC.
Sulistyaningsih, D. R. (2011). Efektifitas Training Efikasi Diri Pada Pasien Penyakit Ginjal Kronik Dalam Meningkatkan Kepatuhan Terhadap Intake Cairan. Diunduh 28 Januari 2016. Nursing Journal Indonesia University .

Thong, Melissa S.Y, K., \& Adrian. (2007). Social Support Predicts Survaival In Dyalisis Patients. Nephrol Dial Transplant, 22: 845850.

WHO, W. H. (2003). Adherence to long-term therapies: evidence for action. WHO International.

Zimet, G. D., Dahlem, N. W., Zimet, S. G., \& Farley, G. K. (1988). The multidimensional scale of perceived social support. Journal of personality assessment, 52(1), , 30-41 